MEI5

\title{
Solid State Protein Devices
}

Roberto Cingolani

Univ. of Lecce, Italy

roberto.cingolani@unile.it 